\title{
ETHICAL ISSUES IN MARKETING: WITH SPECIAL REFERENCE TO LIBRARY RESOURCE AND SERVICES
}

\author{
Dr.Priyanki Vyas \\ Ms. Kinjal G. Parmar
}

\section{Abstract}

This paper deal with the ethical issues in marketing of library resources and services. With the increasing demand of users library need to promote and market their resource to aware users from library resources and services. Marketing is process of managing profitable relation with customer in ethical manner. Digital era wants to more and more marketing for the wide spread of information in market.Librarian need to follow the ethical behaviour and use the legal tools to promote the resource, service and information of the library.Market of library resource and services impact the usage of library, to increase the library usage library start unethical marketing of product and services. Ethical librarianship promotes the library resources for value added service, avoid ethical issues, and increase the usage of library resources and services through the ethical marketing of resource and services.

Keyword:Marketing, Ethics, Library resource Library services

\section{$\underline{\underline{\text { Introduction }}}$}

Ethics and moral is motto of the life. Without ethics and ethical behaviour people could not find the truth of the life. Ethics help to find what is good and what is bad. While moral help to find what is right and what is wrong. In every field and sector ethics become most important. To provide the service in different sector ethical behaviour help in reaching the best service to the customer. Service provided to customer based on the user's needs and demand for that marketing play very vital role in the trending and developing scenario. Digital era wants to more and more marketing for the wide spread of information in market. Without the marketing of any kind of product and services 
Towards Excellence: An Indexed, Refereed \& Peer Reviewed Journal of Higher Education / Dr.Priyanki Vyas \& Ms. Kinjal Parmar/Page 75-82

customer can't find the resource for them.Organisation becomes handicap without marketing of their service and product. It's an integral part of organisation including library.

Organisation use marketing as tools for customer satisfaction, to promote their resources product, evaluate the image in the market etc. same as other library also do the marketing of their information, resource, product and various services so as to reach the number of user, promote the library service, resource and product, also improve the image of library in the market and in the mind of user's.

All we know that marketing become very important in this digital era. With that some ethics and legal issue should be kept in mind by services provider while marketing the resource, service and product. At the time of marketing people under taken some unethical behaviour for market their resource which impact on the customer need and their future demand.Unethical behaviour and use of illegal tools in marketing impact on the future scenario and customer demand. Librarian need to follow the ethical behaviour and use the legal tools to promote the resource, service and information of the library. Which all thing are play vital role in developing library trend.

\section{Literature Review}

Joseph Jestin and B Parameswari (July, 2005)study about the Marketing of Information Products and Services for Libraries in India, it state that information makes marketing difficult. Information market and library user are consumer of information. Library acquisition, organisation, planning and dissemination of information based on the marketing which satisfy the need of customer.

Anil Kumar (Feb. 2014) conduct the study under Marketing of Information Products \& Services in Kurukshetra University Library in the Disciplines of Social Science: A study, researcher find fact on marketing of information product. Most of the users are ready to pay for the information product, they believe in the quality of information rather than to use the freely available information product and library need to improve their existing services and product for providing satisfactory level of services.

Bhatt, R.K.study about the financial crunches face by the university library in case of marketing of library resource and services in industries. Information resources in university libraries both in print and not print form, most of the fund of the budget or 
Towards Excellence: An Indexed, Refereed \& Peer Reviewed Journal of Higher Education / Dr.Priyanki Vyas \& Ms. Kinjal Parmar/Page 75-82

money spend on the subscription of e resources and result of study evident that extensively used by the faculty, post graduate student and research scholar for their extensive knowledge.

\section{Objectives}

$>$ To know the concept of marketing in library resource and services.

$>$ To understand the ethical issues in marketing of library resource and services.

$>$ To acknowledge the ethics behaviour in marketing of library resources and services.

\section{Definition of Marketing}

"Marketing is the analysis, planning, implementation and control of carefully formulated programs designed to bring about voluntary exchanges of values with target markets for the purpose of achieving organizational objectives. It relies heavily on designing the organization's offering in terms of the target market's needs and desires and as using effective pricing, communication, and distribution to inform, motivate and serve the markets."Philips Kotler (Kotler-2007)

"Marketing is the activity, set of institutions, and processes for creating, communicating, delivering, and exchanging offerings that have value for customers, clients, partners, and society at large."American Marketing Association (2017)

"Marketing is the management process responsible for identifying, anticipating \& satisfying customer requirements efficiently \& profitably".

The UK's Chartered Institute of Marketing

\section{Concept of Marketing in the Library}

Library store the various kind of resources and provide better services to their customer. In the present era many of the users are unknown from the library resource and service. Only through the marketing users are aware from the library resource and service for 
that library needs to market their resource for providing betterservice, and in that case $7 p$ of marketing must be follow for the ethical marketing.

e The 7 Cs model of Marketing provides a framework for businesses that want to increase their customer base and attract repeat customers. The $7 \mathrm{Cs}$ model is a reiteration of the $7 \mathrm{Ps}$ model, refined to be more customer-centric.

\& The 7 Ps include Product, Price, Place, Promotion, Physical evidence, Process and People. In 7 Cs include Customer, Cost, Convenience, Communication, Credibility, Connection and Customer service.

e 7P of Marketing replace with $7 \mathrm{C}$ of Marketing

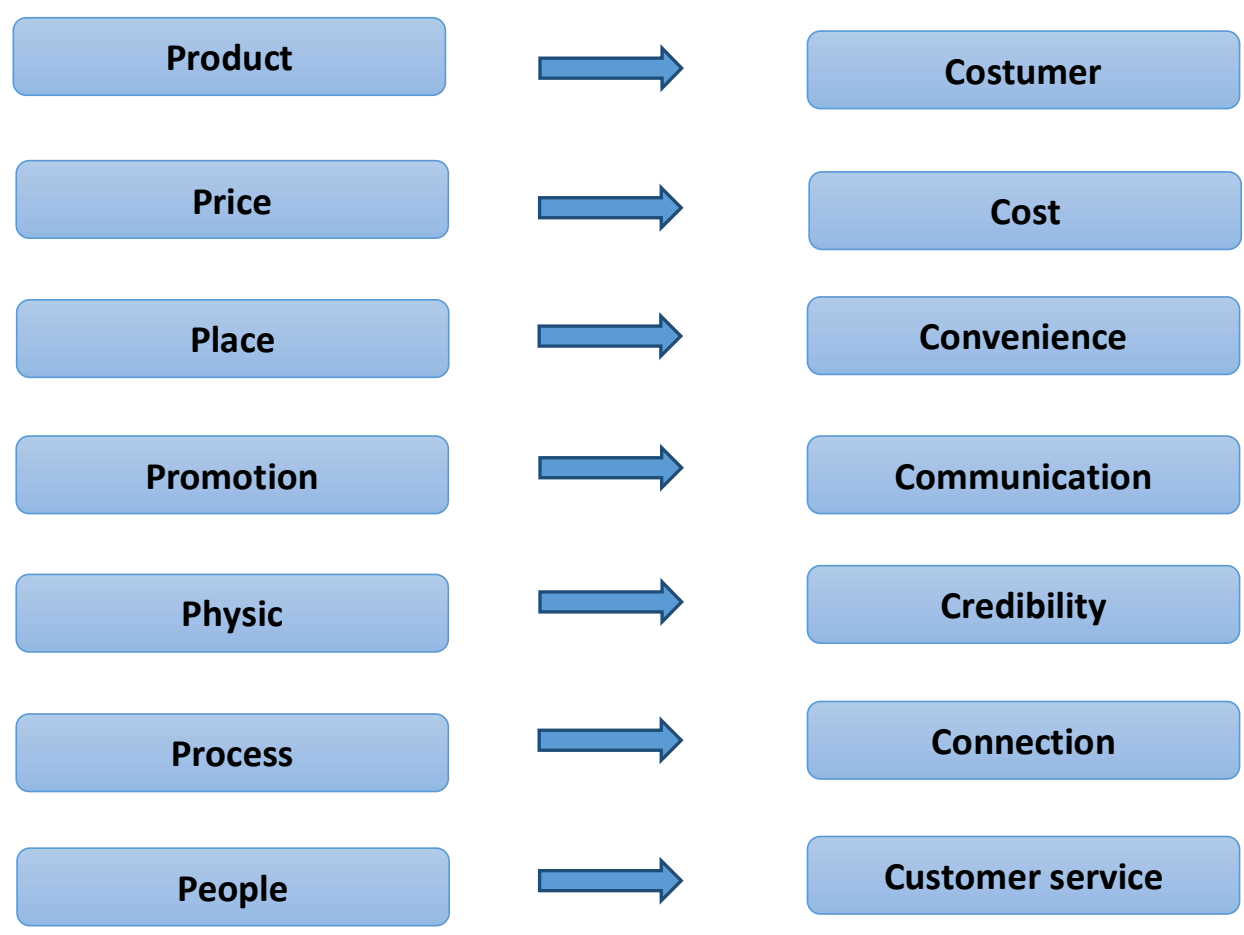

\section{Concept of $7 \mathrm{C}$ in context of library product and services}

e Costumer: The primary focus of marketing is our consumer;he/she is king of market. Where is in library consumer is our users who use the library resources and services. Users are the centre point of library. 
e Cost: It's kind of remuneration of services. Cost become variable from product to product. In the library cost relate with the charges of membership which is given by users in terms of use of library resources and services.

\& Convenience: The main focus of convenience on the easy to buying. Library provides the service $24^{\star} 7$ within and outside the library, which more helpful to the users for physical access and remote access.

\& Communication: Technique of connecting with user for fulfilled their requirement, called communication. It's connection between library and users requirement. With the communicating user library understand the problem of user's and try to solve it.

2 Credibility: With help of various services library can gain more credit among the people as well as users. Gaining more users can increase credibility of library.

\& Connection: Any business wants to connect with their customer for creating brand, image and gain loyalty from market. In libraryconnection can helps to build loyalty and image among the users. Loyalty help library to increase their services for the users.

\& Customer services: Library is service sector and it is growing organism. It is majorly depend on service which is provided to users. So, user (customer) service is most important part of library.

\section{Benefits of Library Marketing}

There are some benefits of library marketing as below

\& Improve the user's satisfaction

2 Efficient of marketing resource

\& Improve the resource and services as per user's expectation

\& Extension of services for potential users 


\section{Ethical issue in marketing of library resource and services}

Marketing is the process of exchange the goods and services for the value of an item. Marketing not only for the promotion, publicity or any other purpose, product creation, pricing and distribution, marketing increase expectation of customer. It connect organisation with society, to provide right product and services to the right customer. Customers are the most important people in the library, they know from the name of users or patrons they are not depend on library rather than library depend on the users. To satisfy their needs in ethical manner its first priority of library. ICT era makes library to work on the digital database in that case libraries have their own social site, library webpage, and various digital link through which library market their product and service digitally and online.

Every libraryhas their own ethics in case of acquisition, services providing, marketing etc. Ethical issues arise only from the conflict and lack of understanding. Some point whereethical issues take place in marketing of (IR \& S)

\section{\& Market Research}

Library use the various sits and network for market research, providing regular and current update to potential users and connect with them easily. Lack of understanding market scenario create ethical issue for users.

\section{e Group of User's}

Marketing divided in different segment of group of user create bias in promoting and marketing library services and product. The first law of library science said that resources are for all it breaks in case of segment marketing. Bias in the users becomes frequent ethical issue in library.

\section{\& Ethics in Advertising and Promotion}

Advertise and promotion of library service against the ethical standard or rules of ethics, consider as ethical issues, marketing based on some ethical standard and rules which help to overcome from the conflict or ethical issue. 


\section{\& Delivery Channels}

Marketing of any product require specific channel to connect with potential users. Use of unauthorised or illegal channel for market of particular product or service against the ethics of human or of organisation. Library marketing scenario show most of people are not aware from the library, its resource, services and function. Broadcasting the product using channel not cover in ethics, create ethical issue for library as well as users.

\section{\& Price of product and services}

Providing the same product and services with different price to the different users and group of users break the ethics and professionalism.Library has same rules and regulation for all past, current and potential users.

\section{\& Internet Marketing}

Providing the resources and service, data full text in legal accessibility limit through internet marketing. Open access data should be copy, it create ethical issue for the copy right holder, for protecting the primary content apply restrictionof accessibility in ethical manner.

\section{Conclusion}

Like the other organisation, library has to market their resource and services to connect with society. At the same time ethics must be there to promote the legal marketing of information resource and service of library. Somehow library or people of library should be bias in case of patron's requirement and take the unethical decision which harms the image and credit of the library. Market of library resource and services impact the usage of library, to increase the library usage library start unethical marketing of product and services.Ethical librarianship promotes the library resources for value added service, avoid ethical issues, and increase the usage of library resources and services through the ethical marketing of resource and services. 


\title{
References
}

Adegoke, Kudirat Abiola. "Marketing of Library and Information Services in University Libraries: A Case Study of UsmanuDanfodiyo University Library, Sokoto-Nigeria." Intellectual Property Rights: Open Access, vol. 03, no. 02, 2015, doi:10.4172/23754516.1000143.

Aluko-ArowoloTitilola, "Ethics and legal issues in the library: A review." Journal of Education Research and Behavioural Sciences, vol. 3, no.10, 2014, pp. 326-329.

Kumar, Anil. "Marketing of Information Products \& Services in Kurukshetra University Library in the Disciplines of Social Science: A Study." IOSR Journal of Humanities and Social Science, vol. 19, no. 2, 2014, pp. 72-85., doi:10.9790/0837-19217285.

Joseph Jestin K.J. \&B.Parameswari,“Marketing of Information Products and Services for Libraries in India." Library Philosophy and Practice,vol. 5, no.1, 2012.

R.K. Bhatt, "Marketing of LIS Products and Services for Industries by the University Libraries: A Strategic Solution to the Problem of Financial Crunch." ADVOCACY AND MARKETING, 2009, pp449-455.

"What Is Marketing? - The Definition of Marketing - AMA." American Marketing Association, www.ama.org/the-definition-of-marketing-what-is-marketing/.

\author{
Dr.Priyanki Vyas \\ Associate Professor \\ Dept. of Library \& Information Science (BAOU) \\ $\&$ \\ Kinjal G Parmar
}

